\title{
Kilka uwag o grzeczności według Wokabularza rozmaitych i potrzebnych sentencji z 1590 roku
}

Anna Burzyńska-Kamieniecka 
nAPOS Seria X 2004

\section{Anna Burzyńska-Kamieniecka}

\section{Kilka uwag o grzeczności według Wokabularza rozmaitych i potrzebnych sentencji z 1590 roku}

Nic bywaj picrwszy w jedzeniu...'

\section{Wprowadzenie}

Wydaje się oczywistym stwierdzenie, że podstawową pomocą wykorzystywaną dawniej i dziś do nauki języka, zarówno ojczystego, jak i obcego, jest podręcznik. Z niego nczący się dowiaduje się nie tylko o regułach gramatycznych i zasadach pisowni, ale także odkrywa obce „światy za słowami”, poznaje obowiązujące w danym kręgu kulturowym sposoby zachowania w różnych sytuacjach kommikacyjnych ${ }^{2}$.

Współczesne podręczniki do języka polskiego dla cudzoziemców wciąż jeszcze za mało mówią - w zasadzie wbrew wielowiekowej tradycji — o pojęciu gr z e c z n ośc i j ę z y kowej, obejmującym, jak zauważa Małgorzata Marcjanik,

...te wszystkie zachowania językowe (...), które regulowane sajednocześnie za pomocą wchodzących w zakres kompetencji kulturowej norm językowych i norm obyczajowych ${ }^{3}$.

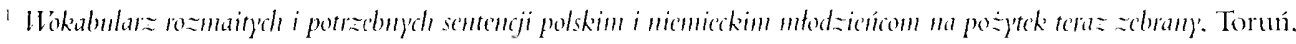
Andr. Cotenius, 1590) k. S6 \%. cytaty w tekścic artykulu zaczerpniç⿻to z tego wydania (follacja w nawiasie zwyklym).

2 Zwlaszcza chodzi tutaj o sytuacje. w których - jak to określa Zenon Leszczyński - obowiązuje „zdecydo-

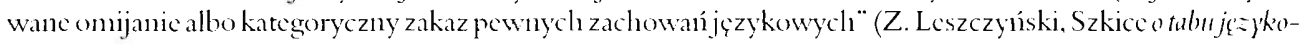
"'j'm, Lublin 1988. s. 10).

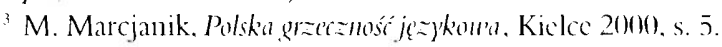


W kontaktach międzykulturowych, do których zwykle dochodzi w trakcie nauczania każdego języka obcego, nieznajomość owych norm często prowadzi do zakłócenia komunikacji, wynikającego z braku umiejętıości prowadzenia skomplikowanej "grzecznościowej gry"

W badaniach nad normami grzecznego zachowania, przestrzeganymi przez konkretną społeczność, warto zatem odwołać się do przeszłości, by w jednym z najstarszych zachowanych do dziś podręczników zrekonstruować skomplikowany system nakazów i zakazów, związanych zwłaszcza z istnieniem ta b u obyczajowego ${ }^{5}$.

Anonimowy Wokabularz rozmaity'ch i potrzebny'ch sentencji polskim i niemieckim mtodzieńcom na poź)te'k teraz zcbrany' prawdopodobnie shuzył do szybkiej nauki języka polskiego, po raz pierwszy ukazał siç w 1539 roku pod tytułem Polskie ksiqże zki u'ielmi potrzebne ku uczenin się pol-

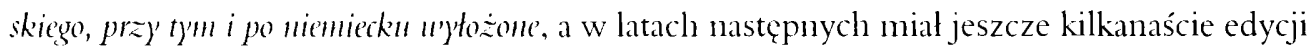
(Królewiec, Toruń, Gdańsk i Wrocław) już jako Wókabulars. Na treść analizowanego dzieła składają się przede wszystkim polsko-niemieckie rozmówki, odnoszące się do wielu sytuacji życia codziennego (choroba, zabiegi higieniczne, przygotowywanie posiłków, zakupy itp.).

W adresowanym do młodego odbiorcy Wokabularzu dominuje antropocentryczny punkt widzenia rzeczywistości, który otwiera bardzo szeroką perspektywę opisywanych zjawisk. Enigmatycznie pojawiający się na kartach książki bohaterowie — młodzież, służba / czeladź (kucharki, szynkarka, słuzą̧ce, dzieci), rodzice, kupcy, goście w karczmie — formułują sądy na temat zdrowia i choroby, nalogów, problemów fimansowych, aktualnych wydarzeń i tym podobnych. Wiele spośród wypowiadanych przez nich fraz ma formę i m per a t y w ó w, skierowanych do anonimowego adresata — potencjalnego użytkownika podręcznika, w których często wskazuje się na konsekwencje nieprzestrzegania określonych nakazów, dotyczących zachowania w konkretnych sytuacjach życia codziennego, jak na przyklad przy przygotowaniu posiłku, pracach porządkowych czy rozrywkach. Pojawiają się również bezosobowe sentencje u moralniające, wypowiadane przez anonimowe autorytety, jak np.:

Dobre słowo jest nade wszystko, tak też kto prawdę powiada, a nie ktamie (B 1).

\section{Przykładowe sytuacje, przykładowe zachowania}

\section{a. Odniesienie do chrześcijańskiego świata wartości}

Material konwersacyjny książki, na który składają się przeważnie niepowiązane tematycznie frazy / sentencje czy też krótkie dialogi, zawiera wiele odwolań do sfery sacrum. Chodzi zwlaszcza o przedstawienie postulowanych relacji człowieka wobec Boga, jak na przyklad w formic nakizów:

\footnotetext{
+ Zob. op. cit. s. 271.

" Chodzi przede wszystkin o sytuacje objęte tabu. wynikające z poczucia wstydu, wspólczucia i litości, ale zwhaszeza z zasad dobrego wychowania.
} 
W czas z loża wstawaj. Przeżegnaj się świçtym Krzyżen w imię Ojca i Syna i Ducha Świętego. Oblecz się w twoje suknic (N 7);

Po obiedzic i po wieczerzy masz Panu Bogı podziękować (O 1).

Niewhaściwe zachowanie bywa nierzadko wiązane z pojęciem grzechu, kary bożej czy gniewu bożego, jak na przyklad:

Ten, co nie słucha ojca ani nuatki, temu nie trzeba radzić, bowiem Bóggo skarze (B 3 l');

Ja nie chcę nic brać ani ruchać, co nie moje jest, grzech jest silny (C 6 t:);

Sam Bóg natomiast jest postrzegany jako sprawca wszelkich zdarzeń:

Żaden włos nie spadnie z głowy naszej bez Bożej woli, których włosów liczbę wie (L 2) -

i to do Niego należy odwolywać się w razie potrzeby:

Cokolwiek w prawej wierze będziemy żądać od Boga, to nam obiecal dać (L 1 l') ;

do Boga należy też zwracać siç w chrwilach zagrożenia:

Miły Boże, uchowaj ciężkiego powietrza (K 4);

Bóg jest sędzią, przed którym trzeba zdać sprawę: Każdy czlowiek musi dać liczbę Panu Bogu na onym świecie (L $8{ }^{\prime}$.).

\section{b. Relacje $z$ rodzicami i przełożonymi (autorytety)}

Po Bogu ziemska władza należy do rodziców, gospodarzy czy właścicieli (nie wolno jej komukolwiek odstępować: „Zła rzecz jest, kiedy rodzice swą wolą dają dzieciom, a zwłaszcza młodym" - K 8) i także do nich odnosi się wiele wypowiedzi (wraz z opisem ewentualnych kar grożących za nieprzestrzeganie określonych zasad), na przykład:

Ku dobremuć nie przyjdzic, coś ty zbroila, jeśli się ociec dowie (C 8);

Ja musze wszego poniechać, a te ryby sprawiać, by pan nie przyszedł, tedy by mnie tajat. (C $3 v$.)

\section{c. Stosunek do osób starszych, w podeszłym wieku}

Osoby starsze, przywoływane na kartach podręcznika, decydują o losie osób mlodszych, które powinny darzyć je szacunkiem:

Starsze czci zawżdy, a miej w poczesności (O 1 ) - 
i czuć wobec nich respekt:

Męże szlachetne, przełożone ludzie miej w wielkiej poczesności (N 8).

Wiek dojrzały, a zwłaszcza starość jest postrzegana jako wyczekiwany etap życia człowieka, do którego zmierza on, zmagając się z przeciwnościami losu:

Chowaj się miemie we wszech rzeczach, w jedzeniu i piciu, tedy doczekasz lat swych (B 1).

Starsi ludzie są jednak czasami krytykowani za związane z wiekiem zachowania, które przeszkadzają młodszym:

Nuże, wy baby stare, przestańcie tego swaru, weźmiecie pogębek, gdy wam rzeką - waruj (O 6).

\section{d. Troska o wygląd i zdrowie}

Do zagadnienia zdrowia i higieny nawiązują wypowiedzi nakazujące troskę o własny wygląd:

Sczesz wlosy, a nie chodź kudlato (N 8);

Jest chędoga rzecz paznogcie obrzezać (M 3 í.).

Onakazie częstego korzystania z zabiegów higienicznych, a równocześnie o przydatności słownictwa dotyczącego tej problematyki, niech świadczy następujący fragment dialogu dwóch słuzą̧cych:

Jako mam rzec, kiedy kto z laźniej wynidzie?

Boże wam daj na zdrowie tę łaźnią (S 5);

Kichającemu co man rzec?

Boże was uzdrów, miły panie, albo: Boże daj wam zdrowie (S 5);

Jako mann rzec, kiedy krew kto puszcza?

Boze daj wann na zdrowie ( $\$$ 5).

\section{e. Postawa wobec śmierci}

Tabuizowana niemal we wszystkich kulturach śm i e r ć nic wydaje się groźna dla anonimowego autora Wokabularza, wspomina o niej kilkakrotnie, wskazując na jej nieuchronność:

Manny się śmierci nadziewać na każdy czas (K 5 l.);

Śmierci a ubóstwa nigdy nie taj, też się nie odrzekaj (P 7 v.). 


\section{f. Stosunek do pieniędzy, kłopoty finansowe}

Wiele dialogów z omawianego zabytku dotyczy tarģı i handlu, dużo mówi się więc o pieniądzach, a zwłaszcza - o ich braku, jak na przyklad:

Kiedy pieniędzy potrzeba, a nie masz gdzie wziąć, ciężka rzecz jest (J 1 l’);

Kto dzisiaj nie ma pieniędzy, za nic u ludzi nie stoi (K 1).

Bardzo często dochodzi do kłopotów z wyegzekwowaniem zaleglych należności, dlugu, na przykład:

Upominam was, zaplaćcie z dobrą wolą, coście wimni, radzę wam (J 6).

Trafiają się także osobliwe propozycje dysponowania majątkiem:

Masz wiele pieniędzy, rozdziel też ze mną połowicę, nie będziesz tego żalowal (B 2).

\section{g. Świat rozrywki (alkohol, hazard, taniec)}

Szesnastowieczni bohaterowie Wokabularza choruja nie tylko z naturalnych przyczyn. Często na ich stan ma wplyw nadmierne spożywanie mocnych trunków, zwłaszcza śląskiego piwa - szepcu:

Chłopi po obiedzie tedy się kwapią na szepc, a jeden pije do drugiego, aż się spiją by świnie (l) 1).

W analizowanym podręczniku tego rodzaju stwierdzenia, pozostające w niezwykłym kontraście z umoralniającymi nakazami, tworzą niezwykłe zderzenie świata sacrum i profanum. Nadmierne picie alkoholı jest z jednej strony przedmiotem krytyki:

Który się rad upija, ten człowiek ani IBoga, ani ludzi w poczciwości ma (L 1 v.)

— ale z drugiej strony stanowi niezbędny element tradycji i należy do dobrego obyczaju:

Dzisiaj obchodzą imię moje, chcę się wanı przepić i chcę wam darować pótgarnca wina, a kiedy wasze imię będzie, zaiste wam nie odpuszczę albo was uwiążę na łańcuchu (I) 4);

Jeśli mi tak wiele nie wypijesz, tedy ja tobie ten kubek o leb sthukę (L 3).

Wiele fraz zawiera realistyczne opisy sytuacji spożywania alkoholu i reakcji fizjologicznych z tym związanych, na przyklad:

Oni pili po polowicy i po pehncj na chlcbnym targu, dziwuję̧ się, jako mogli na nogach stać, niektórzy też taczali się aż w rynsztok (B 4); 
Ostrzegaj się, byś wiele nic pil, abyś nam pościeli nie plugawił (D 1).

Rzeczą, której należy się wystrzegać, ponieważ przynosi szkodę, ale równocześnie daje radość, jest taniec:

Kiedy by tak kucharki kwapiły na kazanie, jako się kwapią do tańca (albo na tum), tedy by też rychlej przyszły do domu i sprawiałyby albo zrobilyby, co by miały sprawić albo zrobić (D) 1 ).

Także i ta rozrywka pozostaje, jak się okazuje, w sferze zakazów:

Będę dzisiaj tańcowała śmiele, bom nie była w niedzielę w kościele (O 6).

Szkodę przynieść może również hazard, dlatego należy się wystrzegać wszelkich gier o pienniądze:

Kostek, warcabów a kart o pieniądze nigdy nie graj (O 2 \%).

\section{h. Cechy charakteru postrzegane jako negatywne}

Bohaterowic I Vokabularza są ludźmi, którzy, oprócz nałogów, powinni wystrzegać się wielu negatywnych cech. Należy zatem zwracać uwagę na etykę wypowiedzi, unikać klamstwa, klótni i sporów:

Dobre slowo jest nade wszystko, tak też kto prawdę powiada, a nie klamie (B 1 v.);

Przestańciè tego swaru z dobrą wolą, matka dała wam powiedzieć, jeśli się pan ociec tego dowie, ostrzegajcie się, sromota i grzech, iz się tak społem gryziecie (C 1).

Należy wystrzegać się używania siły, chociaż jest to jedna z metod wychowawczych, którą stosują starsi:

Chcą mię bić przez winy, muszę się bronić, choć bych nierad chciat (C 8);

Dała mi pięścią w głowę, a jam skarżyła przed matką, tedy i matka jej kijem dała (K 8).

Szczególnie potępia się kradzież:

Cudzej rzeczy nie ruchaj, a niech leży, nič twoje jest, bądź pieniądze, bądź cokolwiek (A 7 r:- $l^{\prime}$ );

Obieszą każdego, co kradnie. Oducz się tego zasię, barzo jest szpetnie (H 7).

Jednakże, mimo iż wokól jest niebezpiecznie, zdarzają się rabunki: 
Obierają też tymi czasy ludzie na drodze ( $135 \%$ \%),

ale nie wszyscy muszą obawiać się kradzièzy:

Ten, kto ma nagą rzyć, nie trzeba mu się przed złodziejem kryć (P 8).

Wśród wielı negatywnych cech piçtnuje się także lenistwo, jak na przykład w pytaniu:

Nie sromasz się tak dlıgo spać? (K + l丷.).

\section{Podsumowanie}

Jak wynika z przywołanych przykładów, omawiany zabytek zawiera bogatą dokumentację obowiązującego w ówczesnym czasie repertuaru zachowań językowych.

Bohaterowie anonimowych dialogów nawiązują do clırześcijańskiego świata wartości, odwołując się do Boga - sprawcy wszech rzeczy, czy wykorzystując pojęcie grzechu i kary bożej. W codziennych zachowaniach starają siç przestrzegać określonych zasad stosownie do obowiązującego wówczas modelu grzeczności, jak na przykład w sytuacji spożywania posiłku:

Nie kladź się łokciem na stól (I I 7 l’):

Nie maż sobie ust tłustym u stohu (I 7 l\%);

Nie jedz lewą ręką, szpetnie jest, ale ucz się prawa je’ść, a ćwicz się (J 2);

Kiedy siędziesz k stołu, siedź prosto, nie mów wicle, a nie kopaj nikogo nogami, tedy cię będą mieć za dobrą a cnotliwą pannę (L 5);

Gdy mówisz, ręce z pokojen trzymaj, a nie rozkladaj po stole (O 1).

Jak zatem widać, zawarte w szesnastowiecznym Vokabularzu normy obyczajowe determinują określone zachowania językowe, wyrażone w postaci nakazów lub zakazów. Imperatywny charakter analizowanych wypowiedzi wiąże się niewątpliwie z funkcją omawianego dziela. Wyraźnie dominuje tutaj c e l w y c how a w c z y, podręcznik pełni rolę nie tylko książki do nauki języka, ale przede wszystkim jest bardzo praktycznym porad n i ki e m, opisującym przykladowe zachowania w codziennych sytuacjach życiowych, co — bez wątpienia różni go od wspólczesnych nam rozmówek dla cudzoziemców. 